\title{
Oxidized Low-Density Lipoprotein and Oxidative Stress in the Development of Glomerulosclerosis
}

\author{
Hyun Soon Lee Chi Young Song \\ Department of Pathology, Seoul National University College of Medicine, Seoul, Korea
}

\section{Key Words}

Angiotensin II - Dyslipidemia - Mesangial matrix $\cdot \mathrm{NADPH}$

oxidase $\cdot$ Reactive aldehydes $\cdot$ TGF- $\beta$ signaling

\begin{abstract}
Glomerulosclerosis frequently complicates most renal diseases and is characterized by mesangial matrix accumulation. Oxidized low-density lipoprotein (Ox-LDL) could induce oxidative stress and profibrotic gene expression in mesangial cells. This article will review our current understanding of the pathogenetic mechanisms of lipid-mediated glomerulosclerosis, emphasizing the fibrogenic signaling cascades triggered by Ox-LDL. In addition, therapeutic strategies to prevent the development of Ox-LDL-mediated glomerulosclerosis will be discussed.
\end{abstract}

Copyright $\odot 2008$ S. Karger AG, Basel

\section{Introduction}

Plasma low-density lipoprotein (LDL) and total cholesterol are markedly elevated in nephrotic syndrome, and lipoprotein abnormalities are common features of the nephrotic syndrome and uremia. One of the deleterious effects of hypercholesterolemia and dyslipidemia on the kidney is enhanced oxidative stress [1-3]. LDL can be oxidized in patients with chronic kidney disease [4-6], and the oxidized LDL (Ox-LDL) seems to participate in the development of glomerulosclerosis and interstitial fibrosis $[7,8]$.

In cultured mesangial cells, LDL and Ox-LDL induce the expression of inflammatory elements, such as platelet-derived growth factor $[9,10]$, monocyte chemotactic protein-1 [11], macrophage colony-stimulating factor [11], interleukin-6 [10, 12], and tumor necrosis factor- $\alpha$ (TNF$\alpha)$ [10]. LDL also stimulates angiotensin II (Ang II) production in mesangial cells [13] (table 1).

Both the glomerulosclerosis and interstitial fibrosis induced by lipid seem to be mediated by activation of transforming growth factor- $\beta$ (TGF- $\beta$ ) $[14,15]$. In cultured mesangial cells, LDL and Ox-LDL activate TGF- $\beta 1$ $[16,17]$, Smad3 [17-19], and extracellular signal-regulated kinase (ERK)1/2 [18, 20, 21]. They also increase the expression of connective tissue growth factor [22] and extracellular matrix (ECM), such as fibronectin [23], types I, III, and IV collagen [9, 16, 22], and plasminogen activator (PA) inhibitor-1 (PAI-1) [17-19, 21, 24] (table 1). In cultured glomerular epithelial cells, Ox-LDL stimulates the expression of TGF- $\beta 1$ and fibronectin [25].

The mechanisms whereby Ox-LDL might induce mesangial matrix accumulation that could culminate in the development of glomerulosclerosis in humans are not clear. In this regard, this review will focus on the fibro-

\section{KARGER}

Fax +41613061234 E-Mail karger@karger.ch www.karger.com (c) 2008 S. Karger AG, Basel

0250-8095/09/0291-006\$26.00/0

Accessible online at:

www.karger.com/ajn
Hyun Soon Lee, MD

Department of Pathology, Seoul National University College of Medicine

Chongno-gu, Yongon-dong 28

Seoul 110-799 (Korea)

Tel. +82 2591 9389, Fax +82 2765 5600, E-Mail hyunsoon@plaza.snu.ac.kr 
genic signaling cascades triggered by Ox-LDL that could lead to oxidative stress and increased mesangial matrix production. In addition, the in vivo effects of Ox-LDL and therapeutic strategies to prevent the development of Ox-LDL-mediated glomerulosclerosis will be discussed.

\section{Nature of Oxidative Stress}

Oxidative stress refers to conditions involving chronically elevated reactive oxygen species (ROS) levels. The excess production of ROS or impaired local antioxidant capacity leads to oxidative stress, which results in the oxidation of proteins, lipids, carbohydrates, and DNA.

Superoxide $\left(\mathrm{O}_{2}^{-}\right)$and hydrogen peroxide $\left(\mathrm{H}_{2} \mathrm{O}_{2}\right)$ seem to be primary ROS generated in the body. $\mathrm{O}_{2}^{-}$is mainly produced by NADPH oxidase in phagocytes participating in bacterial killing [26]. Non-phagocytes including mesangial cells also express the NADPH oxidase complex [27]. Expression of NADPH oxidase is increased in the arteries of atherosclerotic monkeys, but returns toward normal after regression of atherosclerosis [28]. In non-phagocytic cells, the major effects of ROS include regulation of cell growth, activation of numerous signaling molecules as second messengers, and inactivation of nitric oxide (NO) [29]. NO plays a key role in the maintenance of vascular homeostasis and has an antifibrotic effect on mesangial cells [30]. Evidence exists for the presence of increased oxidative stress in chronic kidney disease $[4-6,31]$ and hypertension $[29,31]$.

\section{Lipid Peroxidation of LDL}

LDL is an emulsion of cholesteryl ester stabilized by surface phospholipid, unesterified cholesterol and apolipoprotein B (apoB). Polyunsaturated fatty acids (PUFAs) in cholesterol esters, phospholipids, and triglycerides are particularly sensitive to free radical-initiated oxidation. A key feature of lipid peroxidation is the breakdown of these PUFAs to yield reactive aldehydes such as malondialdehyde (MDA) and 4-hydroxy-2-nonenal [32]. The oxidation of LDL, either by incubation with $\mathrm{CuSO}_{4}$ or cells in culture, causes selective loss of lysine and histidine residues in apoB forming apoB-bound aldehydes [33].

Advanced glycation end product modifications are present on both the apoB and the phospholipid components of LDL in patients with diabetes or end-stage renal disease, which contribute directly to oxidative modifica-
Table 1. Effects of LDL and Ox-LDL on cultured mesangial cells

\begin{tabular}{ll}
\hline Effects & References \\
\hline Proinflammatory effects & \\
Increase PDGF & 9,10 \\
Increase MCP-1, macrophage CSF & 11 \\
Increase IL-6, TNF- $\alpha$ & 10,12 \\
Increase reactive oxygen species & 13 \\
Profibrogenic effects & \\
Increase TGF- $\beta$ & $16,17,21$ \\
Activate Smad3 & $17-19$ \\
Activate ERK & $18,20,21$ \\
Increase CTGF & 22 \\
Increase fibronectin and collagen & $9,16,22,23$ \\
Increase PAI-1 & $17-19,21,24$ \\
Increase tPA and uPA & 24
\end{tabular}

$\mathrm{LDL}=$ Low-density lipoprotein; Ox-LDL = oxidized LDL; PDGF = platelet-derived growth factor; $\mathrm{MCP}-1=$ monocyte chemotactic protein-1; CSF = colony-stimulating factor; IL- $6=$ interleukin-6; TNF- $\alpha=$ tumor necrosis factor- $\alpha$; TGF- $\beta=$ transforming growth factor- $\beta$; ERK = extracellular signal-regulated kinase; CTGF = connective tissue growth factor; PAI-1 = plasminogen activator inhibitor-1; $\mathrm{tPA}=$ tissue-type plasminogen activator; $\mathrm{uPA}=$ urokinase plasminogen activator.

tion of LDL [34]. Molecular events promoted by Ox-LDL could be amplified by coexisting glycoxidation [35].

\section{LDL, Ang II and Oxidative Stress}

Mounting evidence indicates that LDL communicates with the renin-angiotensin system in the development of atherosclerosis [36]. Ang II enhances $\mathrm{O}_{2}^{-}$generation through the activation of membrane-bound NADPH oxidases in vascular smooth muscle cells (VSMCs) [29] and mesangial cells $[13,37,38]$. LDL increases Ang II production, which in turn results in enhanced $\mathrm{O}_{2}^{-}$production in mesangial cells [13]. The LDL, which generates $\mathrm{O}_{2}^{-}$, has already been oxidized, as LDL is rapidly oxidized after its incubation with mesangial cells in serum-free culture media [9]. Ox-LDL decreases the NO synthesis in mesangial cells [39]. Reactive aldehydes within the Ox-LDL tend to trigger the formation of ROS or are oxidants themselves and potentiate oxidative stress in the cells [40].

PKC [37] and Racl [38] are involved in the activation of NADPH-oxidase in Ang II-treated mesangial cells. Racl also mediates the albumin-induced activation of NADPH oxidase in proximal tubule cells [41].

Am J Nephrol 2009;29:62-70 


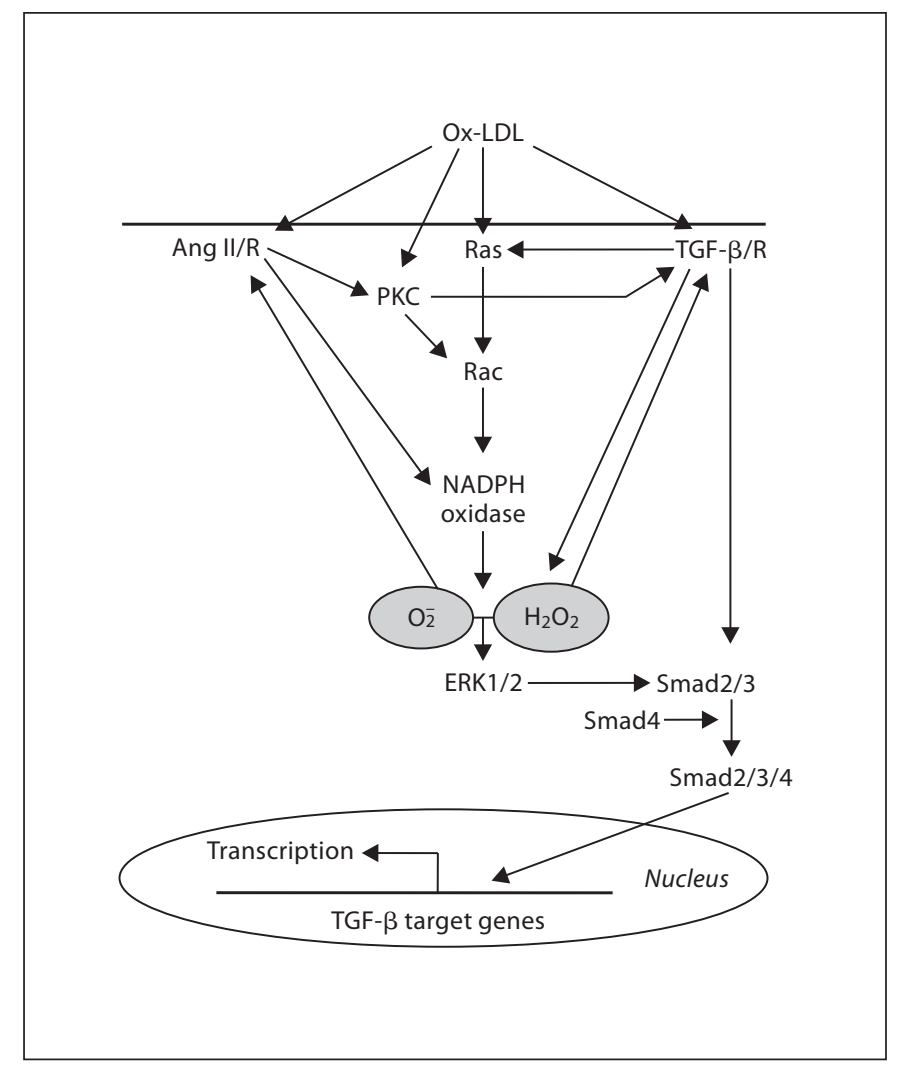

Fig. 1. Proposed model for the activation of fibrogenic signaling via NADPH oxidase by Ox-LDL. Ox-LDL-stimulated Ang II and TGF- $\beta 1$ activate PKC- or Ras-dependent NADPH oxidase via Rac protein in mesangial cells. This process leads to increased reactive oxygen species generation and ERK1/2 activation. The activated ERK1/2 leads to maximal Smad activation resulting in overexpression of TGF- $\beta 1$ target genes. Ox-LDL $=$ Oxidized low-density lipoprotein; Ang II/R = angiotensin II/receptor; TGF- $\beta / \mathrm{R}=$ transforming growth factor- $\beta /$ receptors; $\mathrm{PKC}=$ protein kinase $\mathrm{C}$; ERK1/2 = extracellular signal-regulated kinase 1/2.

\section{Fibrogenic Signaling via NADPH Oxidase Triggered by Ox-LDL}

In contrast to rat mesangial cells having specific receptors for Ox-LDL, the receptors for Ox-LDL are almost negligible in human mesangial cells [42]. Reactive aldehydes within the Ox-LDL seem to be responsible for the effects of Ox-LDL on signaling/transcriptional regulation associated with oxidative stress [43]. They may have no cell surface receptors and react directly with matrix tissue or cells surface proteins [40].

$\mathrm{LDL}, \mathrm{Ox}-\mathrm{LDL}$ and/or MDA increase ECM synthesis in mesangial cells as shown in table 1. LDL also stimulates the mRNA expression of urokinase PA and tissue-type
PA and PAI-1 in mesangial cells [24]. Exogenous TGF- $\beta$ increases the levels of PAI-1 and urokinase PA but does not affect the tissue-type PA production in mesangial cells [44].

Ox-LDL activates the PAI-1 transcription through autocrine activation of TGF- $\beta / \mathrm{Smad}$ signaling in mesangial cells $[17,19]$. TGF- $\beta$ signals through sequential activation of two cell surface receptor serine-threonine kinases [45]. Smad proteins are activated by these receptors, transducing signals to the target genes. In the nucleus, Smad 3 and Smad4 bind preferentially to specific DNA sequences such as CAGA boxes that are present in several TGF- $\beta$ inducible promoters including $\alpha$ (I) collagen, TGF- $\beta 1$ and PAI-1 genes $[19,46]$. Smad 3 activated by Ox-LDL directly binds to two of the three CAGA boxes in the PAI-1 promoter [19]. Smad3, which does not bind directly to the TGF- $\beta$-inducible promoters, might cooperate and interact with general transcription factors to activate transcription $[23,47]$.

Increased oxidative stress has been shown to be a sufficient condition for increased mesangial expression of TGF- $\beta 1$ [48, 49], and ROS activate latent TGF- $\beta$ [50]. TGF- $\beta 1$ protein itself can induce ROS generation in mesangial cells [49].

All of the major mitogen-activated protein kinases in the vasculature are activated by Ang II [51] and $\mathrm{H}_{2} \mathrm{O}_{2}$ [49]. TGF- $\beta$ activates ERK in mesangial cells and ERK is involved in activation of Smad 2 and Smad3 [52]. In fact, TGF- $\beta$-induced ERK activity leads to phosphorylation of the linker segments of Smad2 and Smad3 that results in maximal Smad activation [52, 53].

Ox-LDL activates ERK in mesangial cells through the induction of TGF- $\beta$ signaling pathway, Ras activation, or Rac 1-mediated ROS production [18, 20, 21]. Ox-LDL-induced Ras/ERK activation leads to Smad 3 activation and subsequent overexpression of TGF- $\beta 1$ target genes [21]. Ras or Racl leads to an increase in intracellular ROS formation in fibroblasts, in which Racl functions downstream of Ras [54].

To sum up, these important facts suggest that Ang II and TGF- $\beta 1$ stimulated by Ox-LDL (or its oxidation products) activate PKC- or Ras-dependent NADPH oxidase via Rac protein in mesangial cells. This process leads to increased ROS generation resulting in ERK1/2 activation. The activated ERK1/2 leads to maximal Smad activation resulting in overexpression of TGF- $\beta 1$ target genes in mesangial cells, leading to increased mesangial matrix production (fig. 1). 
Table 2. Targets for prevention of oxidized LDL-induced glomerulosclerosis

\begin{tabular}{|c|c|c|}
\hline Target & Therapeutic approach & References \\
\hline \multirow[t]{5}{*}{ Oxidant } & Vitamins $\mathrm{C}$ and $\mathrm{E}$, probucol & $1,2,4,31,62,70,71$ \\
\hline & $\alpha$-lipoic acid, polyphenols & $72,73,76$ \\
\hline & Histidine and carnosine & 74 \\
\hline & Statins & 4 \\
\hline & Melatonin & 75 \\
\hline \multirow[t]{2}{*}{ PKC } & Vitamin E & 77 \\
\hline & Ruboxistaurin, LY333531 & 78,79 \\
\hline \multirow[t]{3}{*}{ RAS } & AT1 R blocker, ACEI & $13,36,82-87$ \\
\hline & Angiotensin-(1-7) & 88 \\
\hline & TNF- $\alpha$ antagonist & 89 \\
\hline \multirow{4}{*}{$\begin{array}{l}\text { NADPH } \\
\text { oxidase }\end{array}$} & Vitamins $\mathrm{C}$ and $\mathrm{E}$ & 2 \\
\hline & Statins & 90 \\
\hline & Fasudil & 91 \\
\hline & Estrogen & 92 \\
\hline Ras/ERK & Statins & 21 \\
\hline $\begin{array}{l}\text { TGF- } \beta \\
\quad \text { signaling }\end{array}$ & Estrogen (see table 3) & 93 \\
\hline
\end{tabular}

$\mathrm{PKC}=$ Protein kinase $\mathrm{C} ; \mathrm{RAS}=$ renin-angiotensin system; AT1 $\mathrm{R}=$ angiotensin II type I receptor; $\mathrm{ACEI}=$ angiotensin-converting enzyme inhibitor; TNF- $\alpha=$ tumor necrosis factor- $\alpha$; ERK = extracellular signal-regulated kinase.

\section{Clinical Significance of Ox-LDL}

In uremic patients, plasma concentrations of lipid peroxidation products and Ox-LDL are increased [4]. In fact, they are increased in nephrotic or nephritic patients early on before the onset of renal failure $[5,6]$. Dyslipidemia in chronic kidney disease is characterized by reduced clearance of the apoB-containing lipoproteins but misleadingly masked by normal plasma cholesterol levels [55, 56]. Hypercholesterolemia observed in nephrotic syndrome is thought to be due to increased LDL synthesis and impaired LDL clearance [57]. The delayed catabolism in both the nephrotic syndrome and uremia may contribute to increased susceptibility of LDL to oxidation in vitro, as long-lived lipoproteins are more subject to oxidation [58].

In a number of human glomerular diseases, apoBcontaining lipoproteins accumulate within the glomeruli and tubulointerstitium [59]. When the LDL is trapped for a prolonged period of time in the mesangial matrix or tubulointerstitium, it may be oxidized due to depletion of antioxidants found in plasma and extracellular fluid. Furthermore, due to infiltration by neutrophils and monocyte/macrophages in the inflamed glomeruli or in- terstitium, the conditions for LDL oxidation would be favorable. Indeed, Ox-LDL or lipid peroxidation products are demonstrated in the glomeruli and interstitium in renal biopsies [60, 61].

Hypercholesterolemia aggravates glomerular and interstitial macrophage accumulation in a variety of experimental renal diseases $[8,14,62]$. Macrophages have a large number of scavenger receptors (SRs), such as SR-A, CD36 (SR-B) and lectin-like Ox-LDL receptor-1 (SR-E) [63-65]. Because the expression of SRs is not downregulated by intracellular cholesterol [66], macrophages expressing SRs can internalize substantial quantities of cholesterol ester from Ox-LDL present in the diseased glomeruli and interstitium leading to foam cell formation. Once converted into foam cells, internalized lipid peroxide products can activate the cells to produce inflammatory cytokines, chemokines, and growth factors [64], inducing injury and death to surrounding cells resulting in renal fibrosis [67]. In support of this hypothesis, mice deficient in SR-A or CD36 have been reported to show decreased atherosclerosis $[68,69]$.

Altogether, the risk for glomerulosclerosis might be magnified by oxidative stress in the presence of Ox-LDL (or its oxidation products) in the previously injured glomeruli via foam cell formation and mesangial matrix accumulation.

\section{Measures to Inhibit Oxidative Modification of LDL and Ox-LDL-Induced Renal Fibrosis}

\section{Antioxidants}

Dietary supplementation of vitamin E and probucol reduces renal injury in chronic nephrotic rats $[62,70]$. Vitamins $\mathrm{C}$ and $\mathrm{E}$ in experimental hypercholesterolemia decrease LDL oxidizability [1] and interstitial fibrosis [2]. In patients with end-stage renal disease, vitamin E supplementation results in the amelioration of oxidative stress [4, 31] and myocardial infarction [71]. Statins reduce the plasma levels of Ox-LDL in dialysis patients [4].

Green tea and concentrated red grape juice (sources of polyphenols), $\alpha$-lipoic acid, histidine and carnosine, as well as melatonin have antioxidant activity in experimental animals [72-75] and hemodialysis patients [76] (table 2).

\section{PKC Inhibitors}

LDL-induced synthesis of $\alpha 1$ (IV) collagen and PAI-1 mRNAs was inhibited by a PKC inhibitor, GF-109203X, 
Table 3. Modulation of TGF- $\beta$ signaling in oxidized LDL-induced renal fibrosis

\begin{tabular}{lll}
\hline Target & Therapeutic approach & References \\
\hline TGF- $\beta$ /R action & Anti-TGF- $\beta$ antibody & $17,96,97$ \\
& Antisense TGF- $\beta$ 1 ODN & 98 \\
& TGF- $\beta$ RNA interference & 99 \\
& Decorin & 100 \\
& Soluble TGF- $\beta$ type II receptor & 101 \\
& Inhibitor of TGF- $\beta$ receptor & 102,103 \\
& $\quad$ kinases & \\
Smad signaling & Smad7 & 104 \\
& BMP-7 & 105,106 \\
& Hepatocyte growth factor & 107 \\
& TGIF, SnoN & 108,109 \\
\hline
\end{tabular}

TGF- $\beta / R=$ Transforming growth factor $-\beta /$ receptor; ODN = oligodeoxynucleotide; BMP-7 = bone morphogenic protein-7; $\mathrm{TGIF}=$ transforming growth-interacting factor.

in cultured mesangial cells $[16,24]$. Vitamin E reduces PKC-signaled increases in TGF- $\beta$ in mesangial cells [77]. Inhibition of PKC- $\beta$ with LY333531 or ruboxistaurin reduced renal injury and TGF- $\beta$ expression in experimental diabetic nephropathy [78]. In patients with diabetic nephropathy, ruboxistaurin has given supportive results in a pilot study [79] but no effects in other long-term studies [80]. Recently, activation of PKC- $\varepsilon$ in the diabetic state seems to ameliorate the renal fibrosis by inhibiting the TGF- $\beta 1$ signaling [81].

\section{Inhibitors of Renin-Angiotensin System}

Losartan inhibits the LDL-induced increased $\mathrm{O}_{2}^{-}$generation in mesangial cells [13]. Long-term blockade of the renin-angiotensin system seems to have a beneficial effect on uremic dyslipidemia [82]. Losartan reduces oxidative stress, renal fibrosis and TGF- $\beta$ expression in rats with NO deficiency, subtotal nephrectomy, or unilateral ureteral obstruction [83-85]. Olmesartan also prevents renal damage in Imai rats with spontaneous glomerulosclerosis [86]. Clinically, the combination of angiotensinconverting enzyme inhibitors and angiotensin receptor blocker reduces proteinuria more than either agent alone in patients with kidney disease [87].

Angiotensin-(1-7), a vasodilatory compound formed from Ang II, alleviates oxidative stress and renal vascular dysfunction in diabetic hypertensive rats [88].

Hypertension also increased T-lymphocyte production of TNF- $\alpha$, a promoter of fibrosis in the kidney, and treatment with the TNF- $\alpha$ antagonist etanercept pre- vented the Ang II-induced hypertension and increase in vascular $\mathrm{O}_{2}^{-}$[89] (table 2).

\section{Inhibitors of $\mathrm{NADPH}$ Oxidase}

LDL-induced $\mathrm{O}_{2}^{-}$overproduction was suppressed by diphenylene iodonium, a potent NADPH oxidase inhibitor, in mesangial cells [13]. Vitamins $\mathrm{C}$ and $\mathrm{E}$ decrease the expression of NADPH oxidase subunits in hypercholesterolemic pigs [2]. Statins decrease the activity of NADPH oxidase in VSMC by diminishing the geranylgeranylation of Racl [90]. Fasudil, a Rho-kinase inhibitor, attenuates the renal mRNA expression of NADPH oxidase subunits, TGF- $\beta$ and collagen in experimental hypertensive glomerulosclerosis [91] (table 2).

Estrogen also decreases Racl expression and NADPH oxidase activity in VSMC [92]. It prevents the progression of experimental diabetic nephropathy by inhibiting the effects of TGF- $\beta$ [93] (table 2). Estrogen deficiency accelerates while estrogen replacement retards glomerulosclerosis in young sclerosis-prone oligosyndactyly mutant mice [94]. Exceptionally, estrogen contributes to severity of hyperlipidemia and renal injury in Nagase rats with hereditary analbuminemia [95].

\section{Ras/ERK Inhibitors}

Blockade of ERK signaling by PD98059 or UO126, mitogen-activated ERK-activating kinase $1 / 2$ inhibitors, attenuates the Ox-LDL-induced increase in PAI-1 expression in mesangial cells [18]. Lovastatin abrogates the OxLDL-induced Ras and ERK activity resulting in the downregulation of TGF- $\beta 1$ and PAI-1 genes in mesangial cells [21] (table 2).

\section{TGF- $\beta$ Signaling Antagonists}

Inhibitors of TGF- $\beta /$ Receptor Action

Incubation with anti-TGF- $\beta$ or SB-431542, an inhibitor of TGF- $\beta$ type I receptor, decreases Ox-LDL-induced nuclear Smad3 expression and PAI-1 synthesis in mesangial cells [17]. Monoclonal antibody to TGF- $\beta$ (1D11) reduces renal fibrosis in different animal models $[96,97]$. Antisense TGF- $\beta$ oligonucleotides [98] and RNA interference targeting TGF- $\beta 1$ [99] also reduce expression of renal matrix components in animal models. Blockade of TGF- $\beta$ activation by transfer of decorin gene suppresses ECM accumulation in experimental glomerulonephritis [100].

Soluble TGF- $\beta$ type II receptor decreases the renal cortical fibrosis in experimental diabetic nephropathy [101]. Inhibition of TGF- $\beta$ type I receptor kinase (ALK5) also ameliorates renal fibrosis in experimental nephro- 
sis [102]. Recently, oral administration of GW788388, an inhibitor of TGF- $\beta$ type I and II receptor kinases, reduces the renal fibrosis in diabetic mice [103] (table 3).

\section{Inhibitors of Downstream Pathways of TGF- $\beta$}

Signaling

Overexpression of Smad7, an inhibitory factor in TGF$\beta$ signaling, reduces renal fibrosis in rat remnant kidney [104].

Bone morphogenic protein (BMP)-7 counteracts the fibrogenic action of TGF- $\beta$. Supplementation with exogenous BMP-7 suppresses renal fibrosis in experimental renal disease [105]. Maintenance of BMP-7 also reduces renal fibrosis in BMP-7 transgenic mice with diabetic nephropathy [106]

Hepatocyte growth factor (HGF) shows efficacy in ameliorating renal fibrosis in different animal models [107]. HGF antagonizes TGF- $\beta /$ Smad signaling in kidney cells by blocking the nuclear translocation of activated Smad [107] and activation of Smad transcriptional co-repressors, TGIF [108] and SnoN [109] (table 3).
Although supplementation of exogenous BMP-7, HGF and Smad antagonists would eradicate the fibrogenic actions of TGF- $\beta 1$, this has not been tested in humans yet.

\section{Conclusions}

Clinical evidence to support a relationship between Ox-LDL and oxidative stress and progressive, proteinuric kidney disease continues to grow. Experimental data suggest that Ox-LDL (or its oxidation products)-stimulated TGF- $\beta 1$ and Ang II activate NADPH oxidase in mesangial cells resulting in activation of ERK1/2, which leads to maximal Smad activation and subsequent overexpression of TGF- $\beta 1$ target genes. Despite a paucity of studies to test this hypothesis in humans, research on the fibrogenic signaling cascades triggered by Ox-LDL will further our comprehension of the mesangial matrix accumulation and provide new therapeutic strategies to prevent the development of glomerulosclerosis in patients with chronic kidney disease and dyslipidemia.

\section{References}

1 Stulak JM, Lerman A, Porcel MR, Caccitolo JA, Romero JC, Schaff HV, Napoli C, Lerman LO: Renal vascular function in hypercholesterolemia is preserved by chronic antioxidant supplementation. J Am Soc Nephrol 2001;12:1882-1891.

-2 Chade AR, Bentley MD, Zhu X, RodriguezPorcel M, Niemyer S, Amores-Arriaga B, Napoli C, Ritman EL, Lerman A, Lerman LO: Antioxidant intervention prevents renal neovascularization in hypercholesterolemic pigs. J Am Soc Nephrol 2004;15:1816-1825.

-3 Saland JM, Ginsberg HN: Lipoprotein metabolism in chronic renal insufficiency. Pediatr Nephrol 2007;22:1095-1112.

-4 Diepeveen SHA, Verhoeven GWHE, van der Palen J, Dikkeschei LD, van Tits LJ, Kolsters G, Offerman JJ, Bilo HJ, Stalenhoef AF: Effects of atorvastatin and vitamin $\mathrm{E}$ on lipoproteins and oxidative stress in dialysis patients: a randomized-controlled trial. J Intern Med 2005;257:438-445.

5 Fornasieri A, Perugini C, Seccia M, Napodano P, D’Amico G, Bellomo G: Circulating antibodies recognizing oxidatively-modified low-density lipoproteins in patients with IgA nephropathy, membranous glomerulonephritis and focal glomerulosclerosis. J Nephrol 2002;15:349-357.
6 Kuo H-T, Kuo M-C, Chiu Y-W, Chang J-M, Guh J-Y, Chen H-C: Increased glomerular and extracellular malondialdehyde levels in patients and rats with focal segmental glomerulosclerosis. Eur J Clin Invest 2005;35: 245-250.

7 Lee HS: Low-density lipoprotein and glomerulosclerosis, in Razzaque MS (ed): Cellular and Molecular Basis of Fibrogenesis. New York, Kluwer Academic/Plenum Publishers, 2005, pp 45-60.

-8 Okamura DM, Lopez-Guisa JM, Koelsch K, Collins S, Eddy AA: Atherogenic scavenger receptor modulation in the tubulointerstitium in response to chronic renal injury. Am J Physiol Renal Physiol 2007;293:F575F585.

-9 Lee HS, Kim BC, Kim YS, Choi KH, Chung HK: Involvement of oxidation in LDL-induced collagen gene regulation in mesangial cells. Kidney Int 1996;50:1582-1590.

10 Nishida Y, Yorioka N, Oda H, Yamakido M: Effect of lipoproteins on cultured human mesangial cells. Am J Kidney Dis 1997;29: 919-930.

11 Kamanna VS, Pai R, Roh DD, Kirschenbaum MA: Oxidative modification of low-density lipoprotein enhances the murine mesangial cell cytokines associated with monocyte migration, differentiation, and proliferation. Lab Invest 1996;74:1067-1079.
12 Massy ZA, Kim Y, Guijarro C, Kasiske BL, Keane WF, O’Donnell MP: Low-density lipoprotein-induced expression of interleukin-6, a marker of human mesangial cell inflammation: effects of oxidation and modulation by lovastatin. Biochem Biophys Res Commun 2000;267:536-540.

13 Park SY, Song CY, Kim BC, Hong HK, Lee HS: Angiotensin II mediates LDL-induced superoxide generation in mesangial cells. Am J Physiol Renal Physiol 2003;285:F909F915.

14 Ding G, Pesek-Diamond I, Diamond JR: Cholesterol, macrophages, and gene expression of TGF- $\beta 1$ and fibronectin during nephrosis. Am J Physiol Renal Fluid Electrolyte Physiol 1993;33:F577-F584.

15 Eddy AA: Interstitial inflammation and fibrosis in rats with diet-induced hypercholesterolemia. Kidney Int 1996;50:1139-1149.

16 Lee HS, Kim BC, Hong HK, Kim YS: LDL stimulates collagen mRNA synthesis in mesangial cells through induction of PKC and TGF- $\beta$ expression. Am J Physiol Renal Physiol 1999;277:F369-F376.

17 Song CY, Kim BC, Hong HK, Lee HS: Oxidized LDL activates PAI-1 transcription through autocrine activation of TGF- $\beta$ signaling in mesangial cells. Kidney Int 2005; 67:1743-1752. 
18 Hong HK, Song CY, Kim BC, Lee HS: ERK contributes to the effects of Smad signaling on oxidized LDL-induced PAI-1 expression in human mesangial cells. Translat Res 2006; 148:171-179.

$\checkmark 19$ Kim BC, Song CY, Hong HK, Lee HS: Role of CAGA boxes in the PAI-1 promoter in mediating oxidized LDL-induced transcriptional activation in mesangial cells. Translat Res 2007;150:180-188.

20 Dentelli P, Rosso A, Zeoli A, Gambino R, Pegoraro L, Pagano G, Falcioni R, Brizzi MF: Oxidative stress-mediated mesangial cell proliferation requires $\mathrm{RAC}-1 /$ reactive oxygen species production and $\beta 4$ integrin expression. J Biol Chem 2007;282:2610126110.

-21 Song CY, Kim BC, Lee HS: Lovastatin inhibits oxidized LDL-induced PAI-1 and TGF- $\beta 1$ expression via a decrease in Ras/ERK activity in mesangial cells. Translat Res 2008;151: 27-35.

-22 Sohn M, Tan Y, Klein RL, Jaffa AA: Evidence for low-density lipoprotein-induced expression of connective tissue growth factor in mesangial cells. Kidney Int 2005;67:12861296.

23 Akiba S, Chiba M, Mukaida Y, Sato T: Involvement of reactive oxygen species and SP-1 in fibronectin production by oxidized LDL. Biochem Biophys Res Commun 2003; 310:491-497.

>24 Song CY, Kim BC, Hong HK, Kim BK, Kim YS, Lee HS: Biphasic regulation of plasminogen activator/inhibitor by LDL in mesangial cells. Am J Physiol Renal Physiol 2002;283: F423-F430.

25 Ding G, van Goor H, Ricardo SD, Orlowski JM, Diamond JR: Oxidized LDL stimulates the expression of TGF- $\beta$ and fibronectin in human glomerular epithelial cells. Kidney Int 1997;51:147-154.

-26 Sirker A, Zhang M, Murdoch C, Shah AM: Involvement of NADPH oxidases in cardiac remodelling and heart failure. Am J Nephrol 2007;27:649-660.

-27 Jones SA, Hancock JT, Jones OT, Neubauer A, Topley N: The expression of NADPH oxidase components in human glomerular mesangial cells: detection of protein and mRNA for p47phox, and p22phox. J Am Soc Nephrol 1995;5:1483-1491.

-28 Hathaway CA, Heistad DD, Piegors DJ, Miller FJ Jr: Regression of atherosclerosis in monkeys reduces vascular superoxide levels. Circ Res 2002;90:277-283.

29 Paravicini TM, Touyz RM: Redox signaling in hypertension. Cardiovasc Res 2006;71: 247-258.

>30 Keil A, Blom IE, Goldschmeding R, Rupprecht $\mathrm{HD}$ : Nitric oxide down-regulates connective tissue growth factor in rat mesangial cells. Kidney Int 2002;62:401-411.
31 Vaziri ND: Roles of oxidative stress and antioxidant therapy in chronic kidney disease and hypertension. Curr Opin Nephrol Hypertens 2004;13:93-99.

32 Dix TA, Aikens J: Mechanisms and biological relevance of lipid peroxidation initiation Chem Res Toxicol 1993;6:2-18.

33 Esterbauer H, Wäg G, Puhl H: Lipid peroxidation and its role in atherosclerosis. Br Med Bull 1993;49:566-576.

34 Cai W, He JC, Zhu L, Peppa M, Lu C, Uribarri J, Vlassara H: High levels of dietary advanced glycation end products transform low-density lipoprotein into a potent redoxsensitive mitogen-activated protein kinase stimulant in diabetic patients. Circulation 2004;110:285-291.

-35 Napoli C, Lerman LO, de Nigris F, Loscalzo J, Ignarro LJ: Glycoxidized low-density lipoprotein downregulates endothelial nitric oxide synthase in human coronary cells. J Am Coll Cardiol 2002;40:1515-1522.

36 Bro S, Binder CJ, Witztum JL, Olgaard K, Nielsen LB: Inhibition of the renin-angiotensin system abolishes the proatherogenic effect of uremia in apolipoprotein E-deficient mice. Arterioscler Thromb Vasc Biol 2007;27:1080-1086.

37 Jaimes EA, Galceran JM, Raij L: Angiotensin II induces superoxide anion production by mesangial cells. Kidney Int 1998;54:775784.

38 Gorin Y, Ricono JM, Kim N-H, Bhandari B, Choudhury GG, Abboud HE: Nox4 mediates angiotensin II-induced activation of Akt/ protein kinase B in mesangial cells. Am J Physiol Renal Physiol 2003;285:F219-F229.

39 Wu ZL, Liang MY, Qiu LQ: Oxidized lowdensity lipoprotein decreases the induced nitric oxide synthesis in rat mesangial cells. Cell Biochem Funct 1998;16:153-158.

40 Uchida K: Role of reactive aldehyde in cardiovascular diseases. Free Radic Biol Med 2000;28:1685-1696.

41 Whaley-Connell AT, Morris EM, Rehmer N, Yaghoubian JC, Wei Y, Hayden MR, Habibi J, Stump CS, Sowers JR: Albumin activation of $\mathrm{NAD}(\mathrm{P}) \mathrm{H}$ oxidase activity is mediated via Rac1 in proximal tubule cells. Am J Nephrol 2007;27:15-23.

42 Lee HS, Koh HI: Visualization of binding and uptake of oxidized low density lipoproteins by cultured mesangial cells. Lab Invest 1994;71:200-208.

43 Uchida K, Shiraishi M, Naito Y, Torii Y, Nakamura Y, Osawa T: Activation of stress signaling pathways by the end-product of lipid peroxidation: 4-hydroxy-2-nonenal is a potential inducer of intracellular peroxide production. J Biol Chem 1999;274:2234-2242.

44 Baricos WH, Cortez SL, Deboisblanc M, Xin $S$ : Transforming growth factor- $\beta$ is a potent inhibitor of extracellular matrix degradation by cultured human mesangial cells. J Am Soc Nephrol 1999;10:790-795.
45 Blobe GC, Schiemann WP, Lodish HF: Role of transforming growth factor $\beta$ in human disease. N Engl J Med 2000;342:1350-1358.

46 Dennler S, Itoh S, Vivien D, ten Dijke P, Huet S, Gauthier J-M: Direct binding of Smad3 and Smad 4 to critical TGF beta-inducible elements in the promoter of human plasminogen activator inhibitor-type I gene. EMBO J 1998;17:3091-3100.

47 Derynck R, Zhang YE: Smad-dependent and Smad-independent pathways in TGF- $\beta$ family signaling. Nature 2003;425:577-584.

48 Iglesias-de la Cruz MC, Ruiz-Torres P, Alcami J, Diez-Marques L, Ortega-Velazquez R, Chen S, Rodriquez-Puyol M, Ziyadeh FN, Rodriquez-Puyol D: Hydrogen peroxide increases extracellular matrix mRNA through TGF- $\beta$ in human mesangial cells. Kidney Int 2001;59:87-95.

$\checkmark 49$ Wilmer WA, Dixon CL, Hebert C, Lu L, Rovin BH: PPAR- $\alpha$ ligands inhibit $\mathrm{H}_{2} \mathrm{O}_{2}$ mediated activation of transforming growth factor- $\beta 1$ in human mesangial cells. Antioxid Redox Signal 2002;4:877-884

50 Barcellos-Hoff MH, Dix TA: Redox-mediated activation of latent transforming growth factor- $\beta 1$. Mol Endocrinol 1996;10:1077-1083.

-51 Eguchi S, Dempsey PJ, Frank GD, Motley ED, Inagami T: Activation of MAPKs by angiotensin II in vascular smooth muscle cells. Metalloproteinase-dependent EGF receptor activation is required for activation of ERK and p38 MAPK but not for JNK. J Biol Chem 2001;276:7957-7962.

52 Hayashida T, de Caestecker M, Schnaper HW: Cross-talk between ERK MAP kinase and Smad signaling pathways enhances TGF- $\beta$-dependent responses in human mesangial cells. FASEB J 2003;17:1576-1578.

53 Funaba M, Zimmerman CM, Mathews LS: Modulation of Smad2-mediated signaling by extracellular signal-regulated kinase. J Biol Chem 2002;277:41361-41368.

54 Sundaresan M, Yu Z-X, Ferrans VJ, Sulciner DJ, Gutkind S, Irani K, Goldschmidt-Clermont PJ, Finkel T: Regulation of reactive-oxygen-species generation in fibroblasts by Rac1. Biochem J 1996;318:379-382.

55 Ikewaki K, Schaefer JR, Frischmann ME, Okubo K, Hosoya T, Mochizuki S, Dieplinger B, Trenkwalder E, Schweer H, Kronenberg F, Koenig P, Dieplinger H: Delayed in vivo catabolism of intermediate-density lipoprotein and low-density lipoprotein in hemodialysis patients as potential cause of premature atherosclerosis. Arterioscler Thromb Vasc Biol 2005;25:2615-2622.

56 Vaziri ND: Dyslipidemia of chronic renal failure: the nature, mechanisms, and potential consequences. Am J Physiol Renal Physiol 2006;290:F262-F272.

57 Wheeler DC, Bernard DB: Lipid abnormalities in the nephrotic syndrome: causes, consequences, and treatment. Am J Kidney Dis 1994;23:331-336. 
-58 Walzem RL, Watkins S, Frankel EN, Hansen RJ, German JB: Older plasma lipoproteins are more susceptible to oxidation: a linking mechanism for the lipid and oxidation theories of atherosclerotic cardiovascular disease. Proc Natl Acad Sci USA 1995;92:74607464.

59 Lee HS, Lee JS, Koh HI, Ko KW: Intraglomerular lipid deposition in routine biopsies. Clin Nephrol 1991;36:67-75.

60 Lee HS, Kim YS: Identification of oxidized low density lipoprotein in human renal biopsies. Kidney Int 1998;54:848-856.

61 Solin M-L, Ahola H, Haltia A, Ursini F, Montine T, Roveri A, Kerjaschki D, Holthöfer H: Lipid peroxidation in human proteinuric disease. Kidney Int 2001;59:481-487.

62 Lee HS, Jeong JY, Kim BC, Kim YS, Zhang YZ, Chung HK: Dietary antioxidant inhibits lipoprotein oxidation and renal injury in experimental focal segmental glomerulosclerosis. Kidney Int 1997;51:1151-1159.

-63 Moriwaki H, Kume N, Kataoka H, Murase T, Nishi E, Sawamura T, Masaki T, Kita T: Expression of lectin-like oxidized low density lipoprotein receptor-1 in human and murine macrophages: upregulated expression by TNF- $\alpha$. FEBS Lett 1998;440:29-32.

64 de Villiers WJ, Smart EJ: Macrophage scavenger receptors and foam cell formation. J Leukoc Biol 1999;66:740-746.

-65 Podrez EA, Febbraio M, Sheibani N, Schmitt D, Silverstein RL, Hajjar DP, Cohen PA, Frazier WA, Hoff HF, Hazen SL: Macrophage scavenger receptor CD36 is the major receptor for LDL modified by monocyte-generated reactive nitrogen species. J Clin Invest 2000;105:1095-1108.

66 Li AC, Glass CK: The macrophage foam cell as a target for therapeutic intervention. Nat Med 2002;8:1236-1242.

67 Abrass CK: Cellular lipid metabolism and the role of lipids in progressive renal disease. Am J Nephrol 2004;24:46-53.

68 Suzuki H, Kurihara Y, Takeya M, et al: A role for macrophage scavenger receptors in atherosclerosis and susceptibility to infection. Nature 1997;386:292-296.

-69 Febbraio M, Podrez EA, Smith JD, Hajjar DP, Hazen SL, Hoff HF, Sharma K, Silverstein RL: Targeted disruption of the class B scavenger receptor $\mathrm{CD} 36$ protects against atherosclerotic lesion development. J Clin Invest 2000;105:1049-1056.

-70 Trachtman H, Schwob N, Maesaka J, Valderrama E: Dietary vitamin E supplementation ameliorates renal injury in chronic puromycin aminonucleoside nephropathy. J Am Soc Nephrol 1995;5:1811-1819.

71 Boaz M, Smetana S, Weinstein T, Matas Z, Gafter U, Iaina A, Knecht A, Weissgarten Y, Brunner D, Fainaru M, Green MS: Secondary prevention with antioxidants of cardiovascular disease in end stage renal disease (SPACE): randomized placebo-controlled trial. Lancet 2000;356:1213-1218.
72 Obrosoba IG, Fathallah L, Liu E, NouroozZadeh J: Early oxidative stress in the diabetic kidney: effect of DL- $\alpha$-lipoic acid. Free Radic Biol Med 2003;34:186-195.

73 Frei B, Higdon JV: Antioxidant activity of tea polyphenols in vivo: evidence from animal studies. J Nutr 2003;133:32795-32845.

74 Lee YT, Hsu CC, Lin MH, Liu KS, Yin MC Histidine and carnosine delay diabetic deterioration in mice and protect human low density lipoprotein against oxidation and glycation. Eur J Pharmacol 2005;513:145150.

75 Quiroz Y, Ferrebuz A, Romero F, Vaziri ND Rodriguez-Iturbe B: Melatonin ameliorates oxidative stress, inflammation, proteinuria, and progression of renal damage in rats with renal mass reduction. Am J Physiol Renal Physiol 2008;294:F336-F344.

76 Castilla P, Echarri R, Davalos A, Cerrato F, Ortega H, Teruel JL, Lucas MF, GomezCoronado D, Ortuno J, Lasuncion MA: Concentrated red grape juice exerts antioxidant, hypolipidemic, and anti-inflammatory effects in both hemodialysis patients and healthy subjects. Am J Clin Nutr 2006;84: 252-262.

77 Studer RK, Craven PA, DeRubertis FR: Antioxidant inhibition of protein kinase $\mathrm{C}$-signaled increases in transforming growth factor- $\beta$ in mesangial cells. Metabolism 1997; 46:918-925.

78 Kelly DJ, Chanty A, Gow RM, Zhang Y, Gilbert RE: Protein kinase $C \beta$ inhibition attenuates osteopontin expression, macrophage recruitment, and tubulointerstitial injury in advanced experimental diabetic nephropathy. J Am Soc Nephrol 2005;16:1654-1660.

79 Tuttle KR, Bakris GL, Toto RD, McGill JB, HuK, Anderson PW: The effect of ruboxistaurin on nephropathy in type 2 diabetes. Diabetes Care 2005;28:2686-2690.

80 Tuttle KR, McGill JB, Haney DJ, Lin TE, Anderson PW, PKC-DRS, PKC-DMES, and PKD-DRS 2 Study Groups: Kidney outcomes in long-term studies of ruboxistaurin for diabetic eye disease. Clin J Am Soc Nephrol 2007;2:631-636

81 Meier M, Menne J, Park J-K, Holtz M, Gueler F, Kirsch T, Schiffer M, Mengel M, Lindschau C, Leitges M, Haller H: Deletion of protein kinase $\mathrm{C}-\varepsilon$ signaling pathway induces glomerulosclerosis and tubulointerstitial fibrosis in vivo. J Am Soc Nephrol 2007; 18: 1190-1198.

82 Ichihara A, Hayashi M, Kaneshiro Y, Takemitsu T, Homma K, Kanno Y, Yoshizawa M, Furukawa T, Takenaka T, Saruta T: Low doses of losartan and trandolapril improve arterial stiffness in hemodialysis patients. Am J Kidney Dis 2005;45:866-874.

83 Boffa J-J, Lu Y, Placier S, Stefanski A, Dussaule J-C, Chatziantoniou C: Regression of renal vascular and glomerular fibrosis: role of angiotensin II receptor antagonism and matrix metalloproteinases. J Am Soc Nephrol 2003; 14:1132-1144.
84 Vaziri ND, Bai Y, Ni Z, Quiroz Y, Pandian R, Rodriguez-Iturbe $\mathrm{B}$ : Intra-renal angiotensin II/AT1 receptor, oxidative stress, inflammation, and progressive injury in renal mass reduction. J Pharmacol Exp Ther 2007;323: 85-93.

-85 Manucha W, Carrizo L, Ruete C, Molina H, Valles P: Angiotensin II type I antagonist on oxidative stress and heat shock protein 70 (HSP) expression in obstructive nephropathy. Cell Mol Biol 2005;51:547-555.

- 86 Rodriguez-Iturbe B, Sato T, Quiroz Y, Vaziri ND: AT-1 receptor blockade prevents proteinuria, renal failure, hyperlipidemia, and glomerulosclerosis in the Imai rat. Kidney Int 2004;66:668-675.

-87 Kunz R, Friedrich C, Wolbers M, Mann JF: Meta-analysis: effect of monotherapy and combination therapy with inhibitors of the renin angiotensin system on proteinuria in renal disease. Ann Intern Med 2008;148:3048.

88 Benter IF, Yousif MH, Dhaunsi GS, Kaur J, Chappell MC, Diz DI: Angiotensin-(1-7) prevents activation of NADPH oxidase and renal vascular dysfunction in diabetic hypertensive rats. Am J Nephrol 2008;28:2533.

89 Guzik TJ, Hoch NE, Brown KA, McCann LA, Rahman A, Dikalov S, Goronzy J, Weyand C, Harrison DG: Role of the T cell in the genesis of angiotensin II induced hypertension and vascular dysfunction. J Exp Med 2007;204:2449-2460

90 Wassmann S, Laufs U, Müller K, Konkol C, Ahlbory K, Bäumer AT, Linz W, Böhm M, Nickening G: Cellular antioxidant effects of atorvastatin in vitro and in vivo. Arterioscler Thromb Vasc Biol 2002;22:300-305

91 Nishikimi T, Matusoka H: Molecular mechanisms and therapeutic strategies of chronic renal injury: renoprotective effect of Rho-kinase inhibitor in hypertensive glomerulosclerosis. J Pharmacol Sci 2006;100:22-28.

92 Laufs U, Adam O, Strehlow K, Wassmann S, Konkol C, Laufs K, Schmidt W, Böhm M, Nickening G: Down-regulation of Rac-1 GTPase by estrogen. J Biol Chem 2003;278: 5956-5962.

93 Dixon A, Maric C: 17ß-Estradiol attenuates diabetic kidney disease by regulating extracellular matrix and transforming growth factor- $\beta$ protein expression and signaling. Am J Physiol Renal Physiol 2007;293:F1678F1690.

-94 Elliot SJ, Berho M, Korach K, Doublier S, Lupia E, Striker GE, Karl M: Gender-specific effects of endogenous testosterone: female $\alpha$ estrogen receptor-deficient $\mathrm{C} 57 \mathrm{Bl} / 6 \mathrm{~J}$ mice develop glomerulosclerosis. Kidney Int 2007; 72:464-472.

-95 Shin Y, Vaziri ND, Willekes N, Kim CH, Joles JA: Effects of gender on hepatic HMGCoA reductase, cholesterol $7 \alpha$-hydroxylase, and LDL receptor in hereditary analbuminemia. Am J Physiol Endocrinol Metab 2005; 289:E993-E998. 
96 Yu L, Border WA, Anderson I, McCourt M, Huang Y, Noble NA: Combining TGF- $\beta$ inhibition and angiotensin II blockade results in enhanced antifibrotic effect. Kidney Int 2004;66:1774-1784.

$\checkmark 97$ El Chaar M, Chen J, Seshan SV, Jha S, Richardson I, Ledbetter SR, Vaughan ED Jr, Poppas DP, Felsen D: Effect of combination therapy with enalapril and the TGF- $\beta$ antagonist 1D11 in unilateral ureteral obstruction. Am J Physiol Renal Physiol 2007; 292:F1291-F1301.

$\checkmark 98$ Han DC, Hoffman BB, Hong SW, Guo J, Ziyadeh FN: Therapy with antisense TGF$\beta 1$ oligodeoxynucleotides reduces kidney weight and matrix mRNAs in diabetic mice. Am J Physiol Renal Physiol 2000;278: F628-F634.

99 Takabatake Y, Isaka Y, Mizui M, Kawachi H, Shimizu F, Ito T, Hori M, Imai E: Exploring RNA interference as a therapeutic strategy for renal disease. Gene Ther 2005;12: 965-973.

100 Huijun W, Long C, Zhigang Z, Feng J, Muyi $\mathrm{G}$ : Ex vivo transfer of the decorin gene into rat glomerulus via a mesangial cell vector suppressed extracellular matrix accumulation in experimental glomerulonephritis. Exp Mol Pathol 2005;78:17-24.
101 Russo LM, del Re E, Brown D, Lin HY: Evidence for a role of transforming growth factor (TGF)- $\beta 1$ in the induction of postglomerular albuminuria in diabetic nephropathy: amelioration by soluble TGF- $\beta$ type II receptor. Diabetes 2007;56:380388.

102 Grygielko ET, Martin WM, Tweed C, Thornton P, Harling J, Brooks DP, Laping NJ: Inhibition of gene markers of fibrosis with a novel inhibitor of transforming growth factor- $\beta$ type 1 receptor kinase in puromycin-induced nephritis. J Pharmacol Exp Ther 2005;313:943-951.

103 Petersen M, Thorikay M, Deckers M, van Dinther M, Grygielko ET, Gellibert F, de Gouville AC, Huet S, ten Dijke P, Laping NJ: Oral administration of GW788388, an inhibitor of TGF- $\beta$ type I and II receptor kinases, decreases renal fibrosis. Kidney Int 2008;73:705-715.
104 Hou CC, Wang W, Huang XR, Fu P, Chen TH, Sheikh-Hamad D, Lan HY: Ultrasound-microbubble-mediated gene transfer of inducible Smad7 blocks transforming growth factor- $\beta$ signaling and fibrosis in rat remnant kidney. Am J Pathol 2005;166: 761-771.

105 Zeisberg M: Bone morphogenic protein-7 and the kidney: current concepts and open questions. Nephrol Dial Transplant 2006; 21:568-573.

106 Wang S, de Caestecker M, Kopp J, Mitu G, LaPage J, Hirschberg R: Renal bone morphogenetic protein-7 protects against diabetic nephropathy. J Am Soc Nephrol 2006; 17:2504-2512.

107 Liu Y: Hepatocyte growth factor in kidney fibrosis: therapeutic potential and mechanisms of action. Am J Physiol Renal Physiol 2004;287:F7-F16.

108 Dai C, Liu Y: Hepatocyte growth factor antagonizes the profibrotic action of TGF- $\beta$ in mesangial cells by stabilizing Smad transcriptional corepressor TGIF. J Am Soc Nephrol 2004;15:1402-1412.

109 Yang J, Dai C, Liu Y: A novel mechanism by which hepatocyte growth factor blocks tubular epithelial to mesenchymal transition. J Am Soc Nephrol 2005;16:68-78. 